\title{
Discovery of SNP in exon 14 of the ADD1 gene and its association with fatness traits in four meat-type duck populations (Brief Report)
}

\author{
Detektion von SNP im Exon 14 des ADD1 Gens und seine Assoziation \\ mit Fettmerkmalen bei vier Mastenten-Populationen (Brief Report)
}

JIE WANG' ${ }^{1}$ XIAOLIN LIU', YAN WU ${ }^{1,2}$, HONGJING FAN' and SHUISHENG HOU 3

\begin{abstract}
'Animal Science and Technology College, Northwest A\&F University, Shaanxi Key Laboratory of Molecular Biology for Agriculture, Yangling, People's Republic of China, Institute of Animal Husbandry and Veterinary, Hubei Academy of Agricultural Science, Wuhan, People's Republic of China, ${ }^{3}$ Institute of Animal Sciences, Chinese Academy of Agricultural Sciences, Beijing, People's Republic of China
\end{abstract}

\section{Background}

Fatness traits are important economically traits in meat producing animals including duck (WU et al. 2008a, b). In human, the a-Adducin (ADD1) gene polymorphism was associated with blood pressure and other subsequent negative effects related to obesity, cardiovascular and renal failure. In fact, there was some relationship between obesity and hypertension. Thus the $A D D 1$ gene is a candidate gene for fatness traits and the study aims to invest the relationship between the polymorphism of the $A D D 1$ gene and fatness and growth traits.

\section{Procedures}

The chicken ADD1 gene sequence (NM_001079730.1) was used for primer design (GSP1-F, 5'-AAA GGA GGA AGG GAG ATG-3' and GSP1-R, 5'-GGA CTT TCC TG GAG ATT C-3') and SNP discovery. $\mathrm{PCR}$ program: 4 min at $95^{\circ} \mathrm{C}, 33$ cycles of $30 \mathrm{~s}$ at $95^{\circ} \mathrm{C}, 30$ s at $54^{\circ} \mathrm{C}$ and $30 \mathrm{~s}$ at $72^{\circ} \mathrm{C}$ and final extension at $72^{\circ} \mathrm{C}$ for $10 \mathrm{~min}$. PCR reactions were carried out in total volumes of 15 $\mu \mathrm{L}$ with $40 \mathrm{ng}$ of genomic DNA, 0.5 pmol of each primer, $1.5 \mu \mathrm{L} 10 \times$ buffer, $1.5 \mathrm{mM} \mathrm{MgCl}_{2}, 0.25$ $\mathrm{mM}$ dNTPs and $1.5 \mathrm{U}$ Taq DNA polymerase.

The population we used for SNP identification in ADD1 exon 14 were Z2 (maternal line), Z4 (paternal line), hybrid lines of Peking duck and selected Cherry Valley duck (in total 377 individuals). All birds were raised in floor pens and fed commercial corn-soybean diets that met NRC requirements, and were slaughtered at 8 weeks of age. Carcass weight, eviscerated weight, breast muscle weight, leg muscular, abdominal fat weight (AFW), subcutaneous fat plus skin weight (SFW) and intramuscular fat (IMF) were measured. Three PCR fragments from different SSCP patterns in different populations were subcloned into T-vectors (TianGen) and sequenced. Sequencing reactions were performed using BigDye Terminator chemistry and resolved on an ABI PRISM 3730 DNA sequencer. Association analyses between the SNPs and traits in 377 ducks were performed using SPSS13.0 with the following model: 


$$
Y=\mu+G+L+G \cdot L+e
$$

where $Y$ is the dependent variable (analysed traits), $\mu$ is overall mean, $G$ is the genotype of $A D D 1$ exon 14 (GG, $A A$ and $G A), L$ is the duck population, $G \cdot L$ is the interaction between genotype and duck population (it is a fixed effect) and $e$ is the random error.

\section{Results}

The amplified fragment of exon 14 was approximately 166 bp in size and exhibited polymorphism in different individuals and populations. Three band patters could be identified for exon 14 of the ADD1 gene, which were the products of two alleles (G and $A$ ).

But the alteration of exon 14 (G2193A of NM_001079730.1) was synonymous and did not result in an amino acid change. Association analysis revealed that the homozygous (GG) birds had significant higher SFW than homozygous (AA) in Z2. The homozygous (GG) birds had significant higher carcass weight than the heterozygote (GA) in Z4. The homozygous (GG) birds had significant lower IMF than homozygous (AA) in Cherry Valley duck. The homozygous (GG) birds had significant higher leg muscular weight than homozygous (AA) and the homozygous (GG) birds had lower percentage of AFW than heterozygote (GA) and homozygous (AA) in Hybrid Peking duck. Though the frequency of genotype AA was quite low in the populations and there was no consistent association of $A D D 1$ across all populations the study promotes $A D D 1$ as a candidate gene for growth and fatness traits.

Table 1

Table Least square analysis between exon-14 of $A D D 1$ gene and fatness traits in ducks Analyse zwischen Exon 14 SNP von ADD1 und Fettmerkmalen bei Enten

\begin{tabular}{|c|c|c|c|c|}
\hline \multirow[t]{2}{*}{ Population } & \multirow[t]{2}{*}{ Traits } & \multicolumn{3}{|c|}{ Genotype } \\
\hline & & GG & $\mathrm{AA}$ & GA \\
\hline Peking duck Z2 & SFW, $g$ & $\begin{array}{c}598.0 \pm 12.7^{a} \\
(n=37)\end{array}$ & $\begin{array}{c}535.5 \pm 38.6^{b} \\
(n=4)\end{array}$ & $\begin{array}{c}562.8 \pm 10.6^{\mathrm{ab}} \\
(\mathrm{n}=53)\end{array}$ \\
\hline Peking duck Z4 & carcass weight, g & $\begin{array}{c}2795.3 \pm 43.8^{a} \\
(n=31)\end{array}$ & $\begin{array}{c}2746.2 \pm 67.62^{a b} \\
(n=13)\end{array}$ & $\begin{array}{c}2678.5 \pm 34.1^{b} \\
(n=51)\end{array}$ \\
\hline Cherry Valley duck & intramuscular fat, \% & $\begin{array}{c}3.94 \pm 0.15^{b} \\
(n=28)\end{array}$ & $\begin{array}{c}4.53 \pm 0.20^{\mathrm{a}} \\
(\mathrm{n}=16)\end{array}$ & $\begin{array}{c}4.13 \pm 0.11^{\text {ab }} \\
(\mathrm{n}=54)\end{array}$ \\
\hline Hybrid Peking duck & leg muscular weight, g & $\begin{array}{c}124.1 \pm 2.3^{\mathrm{a}} \\
(\mathrm{n}=51)\end{array}$ & $\begin{array}{c}104.7 \pm 9.5^{b} \\
(n=3)\end{array}$ & $\begin{array}{c}123.9 \pm 2.8^{a} \\
(n=36)\end{array}$ \\
\hline & percentage of AFW, $\%$ & $\begin{array}{c}4.31 \pm 0.13^{b} \\
(n=51)\end{array}$ & $\begin{array}{c}5.45 \pm 0.53^{a} \\
\quad(n=3)\end{array}$ & $\begin{array}{c}4.76 \pm 0.15^{\mathrm{ab}} \\
\quad(\mathrm{n}=36)\end{array}$ \\
\hline
\end{tabular}

a,b denoted significant difference $(P<0.05)$

\section{Acknowledgements}

This work was supported by Eleventh Five-year Program in China (Grant No.2006BAD14B06). The author would like to thank Institute of Animal Science of Chinese Academy of Agriculture Science for collecting samples. 


\section{References}

Wu Y, Liu X, Hou S, Wang J (2008) Single nucleotide polymorphism discovery of peroxisome proliferatorsactivated receptors gamma gene and its association with carcass traits in duck. Arch Tierz 51, 276-82

Wu Y, Liu X, Hou S, Wang J, Liu Y, Kong X (2008) An intronic SNP of PPARG and its association with fat traits in four meat-type duck populations (Brief report). Arch Tierz 51, 199-200

Received 26 October 2009, accepted 21 July 2010.

Corresponding author:

XIAOLIN LIU

email: liuxiaolin@nwsuaf.edu.cn

Animal Science and Technology College, Northwest A\&F University, Shaanxi Key Laboratory of Molecular Biology for Agriculture, Yangling 712100, People's Republic of China 